\title{
Expert panel consensus recommendations for diagnosis and treatment of secondary osteoporosis in children
}

Rocío Galindo-Zavala ${ }^{1 *} \mathbb{D}$, Rosa Bou-Torrent ${ }^{2}$, Berta Magallares-López ${ }^{3}$, Concepción Mir-Perelló ${ }^{4}$, Natalia Palmou-Fontana ${ }^{5}$, Belén Sevilla-Pérez ${ }^{6}$, Marta Medrano-San Ildefonso ${ }^{7}$, Ma $^{a}$. Isabel González-Fernández ${ }^{8}$, Almudena Román-Pascual ${ }^{9}$, Paula Alcañiz-Rodríguez ${ }^{10}$, Juan Carlos Nieto-Gonzalez ${ }^{11}$, Mireia López-Corbeto ${ }^{12}$ and Jenaro Graña-Gil ${ }^{13,14}$

\begin{abstract}
Background: Osteoporosis incidence in children is increasing due to the increased survival rate of patients suffering from chronic diseases and the increased use of drugs that can damage bones.

Recent changes made to the definition of childhood osteoporosis, along with the lack of guidelines or national consensuses regarding its diagnosis and treatment, have resulted in a wide variability in the approaches used to treat this disease.

For these reasons, the Osteogenesis Imperfecta and Childhood Osteoporosis Working Group of the Spanish Society of Pediatric Rheumatology has sounded the need for developing guidelines to standardize clinical practice with regard to this pathology.

Methods: An expert panel comprised of 6 pediatricians and 5 rheumatologists carried out a qualitative literature review and provided recommendations based on evidence, when that was available, or on their own experience. The level of evidence was determined for each section using the Oxford Centre for Evidence-based Medicine (CEBM) system. A Delphi survey was conducted for those recommendations with an evidence level of IV or V. This survey was sent to all members of the SERPE. All recommendations that had a level of agreement higher or equal to $70 \%$ were included.

Results: Fifty-one recommendations, categorized into eight sections, were obtained. Twenty-four of them presented an evidence level 4 or 5, and therefore a Delphi survey was conducted. This was submitted electronically and received a response rate of $40 \%$. All recommendations submitted to the Delphi round obtained a level of agreement of $70 \%$ or higher and were therefore accepted.

Conclusion: In summary, we present herein guidelines for the prevention, diagnosis and treatment of secondary childhood osteoporosis based on the available evidence and expert clinical experience. We believe it can serve as a useful tool that will contribute to the standardization of clinical practice for this pathology. Prophylactic measures, early diagnosis and a proper therapeutic approach are essential to improving bone health, not only in children and adolescents, but also in the adults they will become in the future.
\end{abstract}

Keywords: Secondary osteoporosis, Children, Low bone mineral density

\footnotetext{
* Correspondence: rociogalin@hotmail.com

'UGC Pediatría. Sección Reumatología Pediátrica, Hospital Regional

Universitario de Málaga, Málaga, Spain

Full list of author information is available at the end of the article
}

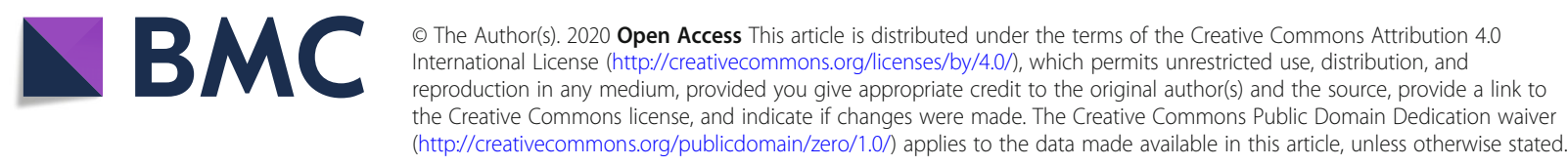




\section{Background}

Osteoporosis is a disorder characterized by bone mass reduction and alterations in the micro-architecture of the bone tissue resulting in bone fragility and, consequently, an elevated risk of fractures [1]. At present, osteoporosis is a public health problem in industrialized countries affecting about $30 \%$ of women and $8 \%$ of men older than 50 in Europe [2]. Although it has typically been considered an adult disorder, it is becoming increasingly clear that osteoporosis might be rooted in childhood and adolescence [3]. Bone matrix mineralization takes place during these stages of life, and therefore subjects reach peak bone mass at the end of this growth phase. If this peak is not optimal, it will facilitate the development of osteoporosis in adulthood [3].

Furthermore, the incidence of childhood osteoporosis is increasing due to, among other factors, the increased survival rate of patients suffering from chronic diseases and the increased use of drugs that can damage bones [4].

In its Official Positions published in 2013, the International Society for Clinical Densitometry considered two possible conditions regarding the diagnosis of childhood osteoporosis [5]:

- Presence of one or more vertebral fractures (VF) in the absence of local disease or high-energy trauma.

- Z-score of bone mineral density (BMD) or bone mineral content $(B M C) \leq-2$ (adjusted for size in cases of children measuring below the 3rd percentile) and a history of clinically significant fractures; specifically:

- two or more long bone fractures occurring by age 10 years; or

- three or more long bone fractures at any age up to age 19 years.

Moreover, their guidelines state that a Z-score higher than -2 does not preclude the possibility of bone fragility, especially in those patients suffering from disorders that favor secondary osteoporosis.

At present, in pediatrics there is growing interest in this pathology. However, recent changes made to the definition of childhood osteoporosis [5, 6], along with the lack of guidelines or national consensuses regarding its diagnosis and treatment, have resulted in a wide variability in the approaches used to treat this disease [7].

For these reasons, the Working Group of Osteogenesis Imperfecta and Childhood Osteoporosis of the Spanish Society of Pediatric Rheumatology (SERPE, by its Spanish acronym) has sounded the need for developing guidelines to standardize clinical practice with regard to this pathology.

\section{Methods}

Design

A qualitative synthesis of scientific evidence and consensus based on clinical experience and existing scientific evidence was used to formulate the study design.

\section{Development stages}

Preparation began with the establishment of an expert panel comprised of 11 physicians, 6 pediatricians and 5 rheumatologists. All are members of the SERPE and have experience in the diagnosis and treatment of secondary osteoporosis in children.

Study coordination was undertaken by one of the physicians.

This panel of experts reached a consensus on the essential contents to include in the document, consisting of the following eight sections:

1. When osteoporosis should be suspected

2. How to prevent it

3. Laboratory tests used in screening

4. Imaging tests used in screening

5. Treatment: calcium and vitamin D supplementation

6. Treatment: bisphosphonates (BPs)

7. Follow-up

8. Glucocorticoid-induced osteoporosis (GIOP)

One or two experts were appointed to be responsible for a literature review of each section, which was conducted with the assistance of a rheumatologist and an expert in methodology.

Following the revision, each of the experts responsible for the literature review provided recommendations regarding each section based on evidence, when that was available, or on their own experience.

Afterwards, the panelists held a meeting to discuss and draft the recommendations. The level of evidence was determined for each section using the Oxford Centre for Evidence-based Medicine (CEBM) system. For this purpose, both a rheumatologist and an expert in methodology provided guidance. A Delphi survey was conducted for those recommendations with an evidence level of IV or V. This survey was sent to all members of the SERPE. All recommendations that had a level of agreement higher or equal to $70 \%$ were included.

\section{Results}

A total of 51 recommendations, categorized into eight sections, were obtained (Table 1). Twenty-four of them presented an evidence level 4 or 5 , and therefore a Delphi survey was conducted. This was submitted electronically and received a response rate of $40 \%$. All recommendations submitted to the Delphi round obtained a level of agreement of $70 \%$ or higher and were therefore accepted. 
Table 1 Recommendations, levels of evidence, grade of recommendation according to the Oxford CEBM and level of agreement in Delphi round*

Recommendation

General recommendations

1 There is a need to monitor BMD in patients with chronic diseases, especially those of endocrinologic, nutritional, rheumatological, renal, metabolic, hematological, neurological and gastrointestinal origin. There is no universal consensus regarding when and how to carry out such an assessment for all the pathologies involved. Following the existing guidelines for each pathology is therefore recommended [8-22].

2 Special attention must be paid to patients with chronic diseases who receive treatments that contribute to osteoporosis development; e.g., GCs, chemotherapy treatments or antiepileptic drugs [17, 19, 20, 23-28].

Lifestyle and dietary habits

3 It is important to identify those children at risk for osteoporosis due to causes related to lifestyle, long-term immobilization or problems of anorexia or malnutrition [19, 29-34].

4 Healthy dietary habits must be established by means of a balanced diet that meets specific calcium and vitamin $D$ requirements for each age and allowing for adequate nutritional intake $[35,36]$.

5 Tobacco, caffeine and alcohol use must be avoided in children and adolescents [35, 37, 38] [39-41].

6 High impact and low frequency exercise - e.g., running or jumping - must be recommended for healthy children and adolescents [31, 42-46].

7 This kind of sport must also be recommended for children with low $\operatorname{BMD}[23,47,48]$.

8 It is important to recommend exposure to sunlight on the hands, face and arms between six to eight minutes/day in the summer (avoiding the hottest part of the day between 10 a.m. and 3 p.m.) and 30 min/day during the coldest months of the year $[15,49,50]$

Complementary test

9 Children with chronic diseases are at greater risk of vitamin D deficiency than the general population. Therefore, it would be advisable to monitor them, mostly during the end of winter [49-51].

10 Regarding all children and adolescents who are suspected of suffering from secondary osteoporosis, the following lab work for the initial study is recommended: blood and urine chemistry, urine screening and bone turnover markers (Table 6) [52].

11 The role of bone turnover makers in pediatric populations with bone fragility is insufficiently defined, but they can be useful 5 in treatment follow-up and evaluation. For this reason, they are included in the initial study of these patients [23, 52-56].

12 Measurements of bone turnover makers in urine are not recommended for all patients since the collection of the sample may be not correctly carried out due to the patient's age or concomitant disease [57].

13 Specific complementary tests detailed in Table 7 can be carried out for some children and adolescents depending on the suspected underlying condition $[15,23,58]$.

14 Interpretation of analytical values must be done taking into consideration the factors that modify them. These factors are biological (age, sex, pubertal stage, ethnicity) and other controllable variables (circadian rhythm, diet, season of the year) $[53,55-61]$.

15 Since low bone mass has been associated with increased fracture risk, DXA is the most recommended method for pediatric populations in order to assess bone health. However, it does not allow for a prediction of fracture risk [34, 48, 62, 63].

16 DXA of the lumbar spine and total body less head (TBLH) is the chosen method to measure BMD in pediatric populations, since they are the most accurate and reproducible areas of the skeletal system for this measurement $[6,64,65]$.

17 Data analyses must be carried out using pediatric software (software for adults overestimates BMD) [66, 67].

18 Vertebrae DXA measurement is recommended for children under the age of five due to its higher reproducibility and shorter time necessary for conducting this test $[5,6,64,66,67]$.

19 For children under the age of three, total body BMD is not recommended on a routine basis due to its lack of reproducibility in such young children; rather BMC should be used [5, 6, 64].

20 Regarding children of short stature $(<\mathrm{p} 3)$ or with a growth retardation problem, it is recommended to adjust their results by means of a size Z-score $[6,23,64,68,69]$.

21 For children suffering from joint contracture or with mobility problems - e.g., with cerebral palsy - distal femur measurement can be an alternative [68]

22 For children with suspected secondary osteoporosis, it is recommended to extend the study with a plain lateral thoracic and lumbar X-ray to assess vertebral compression fractures, particularly if they are receiving GCs [23, 70-73].

23 In the event of low bone mass or risk factor persistence, a second plain lateral thoracic and lumbar X-ray should be taken after one year $[70,71]$.

24 The minimum time interval to wait before repeating a bone density measurement is six months, a period of one year being advisable, apart from exceptional cases $[6,64,66,74,75]$.

LE GR LADR

4 D $95 \%$ 
Table 1 Recommendations, levels of evidence, grade of recommendation according to the Oxford CEBM and level of agreement in Delphi round* (Continued)

\begin{tabular}{|c|c|c|c|c|}
\hline & Recommendation & LE & GR & LADR \\
\hline 25 & $\begin{array}{l}\text { DXA can be used to assess treatment response after six months in the event of high doses of corticosteroids, } \\
\text { chemotherapy, or in situations of malnutrition or active treatment }[6,64,66,74] \text {. }\end{array}$ & $3 b$ & C & \\
\hline 26 & $\begin{array}{l}\text { In cases of children who initially present normal densitometry results, but in whom risk factor(s) persist, the periodicity of } \\
\text { the densitometry must be individualized according to the risk factor associated and an interval of one or two years is }\end{array}$ & 5 & D & $95 \%$ \\
\hline
\end{tabular}
advised until peak bone mass is reached $[6,64,66,74,75]$.

Prevention

27 Oral calcium supplementation could improve BMD in healthy children with a low-calcium diet. Nevertheless, increasing calcium intake by means of calcium-rich foods is preferable to supplementation [36-38, 76].

28 With respect to children with chronic diseases, adequate treatment of the disease is the most important step to be taken regarding osteoporosis prevention and treatment [23, 77-79].

Treatment

29 Vitamin D supplementation must be prescribed for all those patients with chronic pathologies presenting levels lower than $20 \mathrm{ng} / \mathrm{mL}$ and for those with levels between $20-30 \mathrm{ng} / \mathrm{mL}$ who present Z-score $\leq-2$ or any data showing bone fragility [51, $80,81]$.

30 For children and adolescents with a low BMD or osteoporosis, calcium supplementation is recommended, particularly for those patients with a low-calcium diet, as well as supplementation of the proper amount of vitamin $\mathrm{D}_{3}$ in order to keep plasmatic levels of 25 -hydroxyvitamin $\mathrm{D}_{3}$ higher than $30 \mathrm{ng} / \mathrm{dL}[82,83]$.

31 The required amount of calcium and vitamin $D$ supply needed in children with pathologies that can jeopardize intestinal absorption or modify their body's use of these nutrients is unknown. For this reason, in the event that such patients present osteoporosis or low BMD according to chronological age, it is advisable to initially prescribe the dose required to ensure a recommended daily intake of healthy children. Treatment can be modified according to plasmatic 25-hydroxyvitamin $\mathrm{D}_{3}$, iPTH and calciuria levels, which must be monitored every six to twelve months [49-51, 82, 83].

32 Treatment with BP should be administered to those pediatric patients with osteoporosis (Z-score $\leq-2+$ pathological fracture or VF regardless of Z-score) [9, 84-88].

33 Treatment with BP can be considered for patients without osteoporosis, but a low BMD in early puberty (Tanner 2): - When active risk factors are present: patients with $Z \leq-2.5$ SD (with a declining trajectory confirmed at least on two separate occasions with one year apart).

- When patients no longer present active risk factors: patients with $Z \leq-3 D S$ (with a declining trajectory confirmed on at least on two separate occasions with one year apart) $[9,84-87]$.

34 Intravenous BPs should be used whenever there are VF, if there is some contraindication to the use of oral BPs, or according to the patient's preferences [88-91].

35 Oral BPs can be used in the absence of contraindications and VF, or during the de-escalation phase [9, 84-87].

36 The BP dosage should be discontinued or progressively reduced in those patients not presenting fractures during the preceding year and having reached a Z-score higher than -2 [9, 84-87].

Follow-up

37 A follow-up is recommended for patients at risk for osteoporosis while other risk factors persist and during treatment with calcium and/or vitamin $\mathrm{D}_{3}$, BPs or other osteoporosis treatments $[49,51,74]$.

38 Calcium and phosphorus metabolism (serum levels of calcium, phosphorus, alkaline phosphatase, iPTH and 25hydroxyvitamin $D_{3}$ ) should be evaluated on an annual basis $[49,51]$.

39 During treatment with vitamin $D$, it is recommended to monitor serum levels of 25 -hydroxyvitamin $D_{3}$ every 6 to 12 months, unless the dosage is changed. In such cases, patients should be monitored at 3-6 months [49, 51].

40 During supplementation with calcium and/or vitamin $D_{3}$, calcium/creatinine levels in urine should be monitored at least once a year. Renal ultrasounds should be conducted to rule out nephrocalcinosis in the event of calciuria increase, or when it is not possible to determine calciuria due to the patient's age or pathology [49-51, 82, 83].

41 DXA is recommended one year after the baseline DXA, and then subsequently every 1 or 2 years depending on the trajectory observed. The minimum interval should be 6-12 months [74].

42 It is recommended to perform simple lateral thoracic and lumbar X-rays to assess VF every 6 months to 2 years (with 1 year being the average), according to the risk factor magnitude and the functional status of the child $[51,71,74]$.

43 For pediatric patients with reduced mobility due to cerebral palsy and congenital myopathies, a spine X-ray is recommended at 6-8 years of age, or earlier in the event of back pain, and then periodically until the end of growth [23].

44 During treatment with intravenous BPs, assessments of laboratory parameters are recommended before each administration. For oral BPs, checks every six months are recommended [9, 84-86, 88-92].

45 During treatment with BPs, annual DXA is recommended [9, 84-86, 88-92]. 
Table 1 Recommendations, levels of evidence, grade of recommendation according to the Oxford CEBM and level of agreement in Delphi round* (Continued)

\begin{tabular}{|c|c|c|c|c|}
\hline & Recommendation & LE & GR & LADR \\
\hline \multicolumn{5}{|c|}{ Corticosteroid-induced osteoporosis } \\
\hline 46 & $\begin{array}{l}\text { Lateral spine } x \text {-ray is recommended in order to detect VF at the beginning of treatment } \\
\text { with GCs and after one year }[70,71,93] \text {. }\end{array}$ & $2 a$ & B & \\
\hline 47 & $\begin{array}{l}\text { It is recommended to carry out lumbar spine or TBLH DXA within the first six months after the beginning of treatment with } \\
\text { GCs, and then every } 9 \text { to } 12 \text { months if treatment continues [94]. }\end{array}$ & 4 & D & $85 \%$ \\
\hline 48 & $\begin{array}{l}\text { It is recommended to start simultaneous treatment and/ or optimize calcium intake (500-1000 mg/day) and vitamin D } 400 \\
\text { IU/day for those patients who are scheduled to receive systemic GCs for three months or more [95]. }\end{array}$ & $2 b$ & B & \\
\hline 49 & Treatment with calcium and vitamin D must be maintained for three months after discontinuation of GCs [95]. & 5 & $\mathrm{D}$ & $88 \%$ \\
\hline 50 & $\begin{array}{l}\text { For children and adolescents receiving GCs chronically and presenting low BMD (Z-score } \leq-2) \text { and pathological fractures, it } \\
\text { is recommended to use BPs associated with calcium and vitamin D }[87,95,96] \text {. }\end{array}$ & $1 b$ & A & \\
\hline 51 & $\begin{array}{l}\text { Lateral spine } x \text {-rays or BMD checks with DXA are not recommended on a routine basis for those children and adolescents } \\
\text { being treated with inhaled GCs at dosages under } 800 \mathrm{mcg} / \text { day, unless they present other risk factors [97-99]. }\end{array}$ & $1 b$ & A & \\
\hline
\end{tabular}

LE level of evidence, GR grade of recommendation, LADR Level of agreement in Delphi round, GCs glucocorticoids, BMD bone mineral density, BMC bone mineral content, DXA dual-energy x-ray absorptiometry, iPTH intact parathyroid hormone, BPS bisphosphonates, VF vertebral fractures

\section{Discussion}

\section{When osteoporosis should be suspected}

Factors that contribute to osteoporosis in children and adolescents can be both genetic and lifestyle associated.

In children suffering from chronic diseases or receiving bone harmful treatments for a prolonged period of time, several factors that increase bone resorption and decrease bone formation converge and result in increased bone fragility [100] [63]. For this reason, bone health must be assessed during follow-up, adopting adequate preventive measures.

Table 2 shows some of the pathologies responsible for secondary osteoporosis.

There is no universal consensus regarding when and how to assess bone health for all of the pathologies involved. However, there are some clinical guidelines for different pediatric disorders (Table 3 ).

BMD in patients with chronic diseases should be monitored based on the existing guidelines for each disorder. In addition, special attention must be paid to patients suffering from chronic diseases and receiving treatment that may favor the development of osteoporosis; e.g., glucocorticoids (GCs), chemotherapy or antiepileptic drugs.

\section{How to prevent osteoporosis}

There are numerous factors that impact bone health in children. Many of these are modifiable, at least in part (Table 4) [35].

Nutritional factors with higher evidence of conferring a positive effect on bone health are calcium, phosphorus and vitamin D [23]. Table 5 shows the daily nutrient requirements for a healthy child [103], although children suffering from chronic diseases or under treatment with drugs that alter intestinal absorption may need higher intakes of calcium and vitamin D [23, 35, 49, 104].

Calcium-rich foods are preferable to supplements for attaining optimal calcium intake, not only because they have a higher bioavailability [23] and are easier to digest, but also because their consumption avoids possible secondary cardiovascular effects common in adults [105] and favors positive nutritional habits from childhood [23]. Thus, systematic supplementation with calcium in the absence of osteoporosis or low BMD is not recommended [106]. It should only be considered for those patients with calcium-poor diets [42].

Vitamin D is an important hormone for the absorption and use of calcium [103]. There is some dispute regarding the optimal levels of vitamin $\mathrm{D}$, although in general terms, serum levels of 25-hydroxyvitamin $\mathrm{D}_{3} \geq 50 \mathrm{nmol} / \mathrm{L} \quad(20 \mathrm{ng} / \mathrm{mL})$ are considered normal. Those between $30-50 \mathrm{nmol} / \mathrm{L}(12-20 \mathrm{ng} / \mathrm{mL})$ are regarded as insufficient, and those $<30 \mathrm{nmol} / \mathrm{L}(12 \mathrm{ng} / \mathrm{mL})$ deficient [49].

In order to maintain appropriate levels, the intake of food enriched in vitamin D is important, as well as daily exposure to sunlight on the hands, face and arms for 6 to $8 \mathrm{~min}$ in the summer months (avoiding the hottest part of the day) and $30 \mathrm{~min}$ in the coldest months of the year. However, there is no exposure to ultraviolet $B$ (UVB) rays that is safe in terms of skin cancer [49].

Children suffering from chronic diseases have an increased risk of vitamin D deficiency. Therefore, monitoring vitamin D serum levels would be advisable in these patients, especially in late winter [104].

In addition, a large number of other nutrients play a significant role in bone metabolism, such as proteins, potassium, magnesium, copper, iron, phosphate, zinc and vitamin $\mathrm{A}, \mathrm{C}$ and $\mathrm{K}[23,104]$. Thus, it is important 
Table 2 Causes of secondary osteoporosis

\begin{tabular}{|c|c|}
\hline Neuromuscular disorders & $\begin{array}{l}\text { Cerebral palsy } \\
\text { Duchenne muscular dystrophy } \\
\text { Rett syndrome } \\
\text { Myopathies } \\
\text { Diseases resulting in long-term } \\
\text { immobilization }\end{array}$ \\
\hline Hematological diseases & $\begin{array}{l}\text { Leukemias } \\
\text { Hemophilia } \\
\text { Thalassemia }\end{array}$ \\
\hline $\begin{array}{l}\text { Systemic autoimmune } \\
\text { diseases }\end{array}$ & $\begin{array}{l}\text { Juvenile systemic lupus erythematosus } \\
\text { Juvenile dermatomyositis } \\
\text { Systemic juvenile idiopathic arthritis } \\
\text { Systemic sclerosis }\end{array}$ \\
\hline Lung diseases & Cystic fibrosis \\
\hline Gastrointestinal diseases & $\begin{array}{l}\text { Celiac disease } \\
\text { Inflammatory bowel disease } \\
\text { Chronic liver disease } \\
\text { Cow's milk protein allergy }\end{array}$ \\
\hline Renal diseases & $\begin{array}{l}\text { Nephrotic Syndrome } \\
\text { Chronic renal failure }\end{array}$ \\
\hline Psychiatric illnesses & Anorexia nervosa \\
\hline Infectious diseases & $\begin{array}{l}\text { HIV infection } \\
\text { Immunodeficiencies }\end{array}$ \\
\hline Endocrine diseases & $\begin{array}{l}\text { Delayed puberty } \\
\text { Hypogonadism } \\
\text { Turner syndrome } \\
\text { Klinefelter Syndrome } \\
\text { Growth hormone deficiency } \\
\text { Acromegaly } \\
\text { Hyperthyroidism } \\
\text { Diabetes } \\
\text { Hyperprolactinemia } \\
\text { Cushing syndrome } \\
\text { Adrenal insufficiency } \\
\text { Hyperparathyroidism } \\
\text { Vitamin D metabolism disorders }\end{array}$ \\
\hline Inborn errors of metabolism & $\begin{array}{l}\text { Glycogen storage disease } \\
\text { Galactosemia } \\
\text { Gaucher disease }\end{array}$ \\
\hline Skin conditions & Epidermolysis bullosa \\
\hline latrogenesis & $\begin{array}{l}\text { Systemic glucocorticoids } \\
\text { Cyclosporine } \\
\text { Methotrexate } \\
\text { Heparin } \\
\text { Anticonvulsants } \\
\text { Radiation therapy }\end{array}$ \\
\hline
\end{tabular}

to recommend a varied diet, including fruits and vegetables, to ensure an adequate intake of key nutrients in order to maintain good bone health in children and adolescents $[23,35,104]$.

Moreover, exercise and regular physical activity are considered among the most effective strategies for maximizing peak bone mass during childhood [23, 35, 42, 104]. High impact and low frequency exercise - e.g., jumping, running or resistance training - favor BMD increase in children and are more suitable than others such as swimming or biking in terms of bone health [35,
43, 104]. Nevertheless, physical activity with excessive impact increases fracture risk [44].

There are other factors such as tobacco, caffeine and alcohol consumption that are associated with decreased BMD and increased fracture risk [35, 37, 38, 104]. This is one reason, among others, to avoid their consumption in children and adolescents.

It is also essential to maintain an adequate nutritional state because both, extreme thinness and adiposity, are associated with lower BMD and increased fracture risk $[29,30,35]$.

Furthermore, the optimal control of the primary disease is the most effective way to prevent and treat secondary osteoporosis [23, 35].

\section{Diagnosis}

\section{Laboratory tests}

The diagnosis of secondary osteoporosis is usually made after the diagnosis of the underlying disease that causes it. However, in some cases, it may be the first manifestation of the underlying disease. Although most of the disorders included in the differential diagnosis can be inferred by means of a thorough medical history review and physical examination, some pathologies - e.g., phosphocalcic metabolism alterations, hypothyroidism or some types of leukemia- can be paucisymptomatic and require complementary tests for accurate diagnosis [100]. For this reason, it is recommended to perform the analytical parameters listed in Table 6 when assessing a child with suspected or established diagnosis of secondary osteoporosis. Regarding the parameters shown in Table 7, they are only justified in the event of clinical suspicion.

These biochemical parameters must be interpreted based on factors such as age, sex, growth rate, nutritional status and pubertal stage, among others $[52,59]$.

Bone turnover markers are certain substances released into the bloodstream during bone formation or resorption that reflect bone metabolic activity at a given time. Though numerous, amino-terminal propeptides from type 1 procollagen (P1NP) and carboxy-terminal telopeptides (CTx) should be used as reference markers to evaluate formation and resorption, respectively [107, 108]. These can be measured in the blood and urine [109], although for children it is preferable to determine them in plasma $[53,110,111]$. In adults, they have been shown to be useful for monitoring treatment in patients with osteoporosis [112]. In children, however, such interpretation is much more complex [54, 110, 113], although they can help in monitoring antiresorptive therapy compliance and measuring its effectiveness [100].

\section{Imaging tests}

The diagnosis of childhood osteoporosis is essentially based on the presence of fragility fractures. However, a 
Table 3 Assessment of BMD for certain diseases or chronic treatments involved in childhood secondary osteoporosis

\begin{tabular}{|c|c|}
\hline Disease / Treatment & BMD assessment \\
\hline Celiac disease & $\begin{array}{l}\text { DXA if: } \\
\text {-no adequate dietary adherence } \\
\text {-irregular menstruation } \\
\text {-anemia } \\
\text {-other risk factors for fractures [74] }\end{array}$ \\
\hline Cerebral palsy & $\begin{array}{l}\text { Difficult lumbar spine X-ray interpretation in cases of severe scoliosis. } \\
\text { Total-body or distal femur DXA (area with higher fracture risk), only if there are fragility fractures [8]. }\end{array}$ \\
\hline $\begin{array}{l}\text { Duchenne muscular } \\
\text { dystrophy }\end{array}$ & $\begin{array}{l}\text { Baseline DXA and annual monitoring. } \\
\text { Lateral spine } x \text {-ray: Baseline } \\
\text { - On GCs treatment: Repeat every } 1-2 \text { years. } \\
\text { - Not on GCs treatment: Repeat every } 2-3 \text { years. } \\
\text { - If back pain or } \geq 0,5 \text { SD decline in spine BMD Z score on serial measurements over 12-month period: Repeat. } \\
\text { Refer to osteoporosis specialist following the first fracture [11]. }\end{array}$ \\
\hline Rett syndrome & Baseline DXA, and serial controls according to individual risk [15]. \\
\hline Epilepsy & Consider DXA for epileptic patients receiving anti-epileptic drugs for a prolonged period [13] \\
\hline Thalassemia & DXA every 2 years from adolescence [12] \\
\hline $\begin{array}{l}\text { Inflammatory/ systemic } \\
\text { disease }\end{array}$ & Consider DXA for patients receiving high doses of GCs [74]. \\
\hline $\begin{array}{l}\text { Juvenile idiopathic } \\
\text { arthritis (JIA) }\end{array}$ & $\begin{array}{l}<6 \text { years: DXA in the presence of fragility fractures. } \\
>6 \text { years: DXA if not presenting rapid remission of JIA or in need of high doses of GCS [18]. }\end{array}$ \\
\hline Neoplasms & $\begin{array}{l}\text { Baseline DXA two years after completing chemotherapy with osteotoxic drugs; e.g., MTX, GCs or hematopoietic cells } \\
\text { transplantation; or secondary effects that favor osteoporosis development (growth hormone deficiency, hypogonadism, } \\
\text { etc.) } \\
\text { DXA follow-up based on the results of baseline DXA and persistent risk factors [17] }\end{array}$ \\
\hline Cystic fibrosis & $\begin{array}{l}\text { DXA in children } \geq \text { age } 8 \text { if: } \\
\text { - weight }<90 \% \text { ideal weight } \\
\text { - FEV } V_{1}<50 \% \\
\text { - Delayed puberty } \\
\text { - High dosis of } \mathrm{GCS}>90 \text { days per year } \\
\text { At } 18 \text {, all of them [101]. }\end{array}$ \\
\hline Diabetes mellitus & $\begin{array}{l}\text { DXA if: } \\
\text { - low BMD specific risk factors } \\
\text { - increased daily insulin dosis } \\
\text { - impaired renal function } \\
\text { - fracture history [74] }\end{array}$ \\
\hline Anorexia nervosa & DXA in patients with amenorrhea for more than 6 months [13]. \\
\hline $\begin{array}{l}\text { Systemic lupus } \\
\text { erythematosus }\end{array}$ & $\begin{array}{l}\text { DXA evaluation in patients with prolonged systemic GCs exposure exceeding } \geq 0.15 \mathrm{mg} / \mathrm{kg} \text { daily for } \geq 3 \text { months. Repeat } \\
\text { on an annual basis if } Z \text {-score } \leq-2[102] \text {. }\end{array}$ \\
\hline
\end{tabular}

DXA dual-energy $\mathrm{x}$-ray absorptiometry, BMD bone mineral density, GCs glucocorticoids, MTX methotrexate, $F R$ risk factors

dual-energy $\mathrm{x}$-ray absorptiometry (DXA) is recommended to ensure a complete assessment of bone health [5].

Despite numerous limitations [100], DXA is the chosen method for determining bone health in children. Lumbar spine and total-body less head are the preferred skeletal sites for performing DXA as they are the most accurate and reproducible areas in children. In addition, Z-score should be adjusted according to the height in children with a size below the 3rd percentile [5].

Other techniques for assessing bone quality in pediatrics are peripheral quantitative computed tomography and ultrasound. However, although superior to DXA in certain aspects, there are insufficient studies of pediatric populations to recommend their use on a routine basis [100].

Furthermore, in a patient with suspected or confirmed bone fragility, the presence of VF, which are frequently asymptomatic, should always be assessed by means of a simple lateral full spine $\mathrm{x}$-ray or by DXA vertebral fracture assessment, if feasible $[39,114]$.

\section{Treatment \\ Calcium and vitamin D supplementation}

Calcium and vitamin D supplementation have not shown any clinically significant effect on BMD in studies performed in healthy children [106]. In contrast, some studies have reported a favorable effect in patients with chronic diseases that favor osteoporosis such as cerebral palsy [8]. On the other hand, no side effects have been reported $[8,40]$. Thus, although there are no studies that assess the effect of supplementation on the incidence of fractures, calcium supplementation is considered 
Table 4 Risk factors of osteoporosis in childhood

\begin{tabular}{|c|c|c|}
\hline \multirow[t]{2}{*}{ Modifiable } & Nutritional & $\begin{array}{l}\text { - Caloric intake } \\
\text { - Protein intake } \\
\text { - Calcium intake } \\
\text { - Phosphorus intake } \\
\text { - Vitamin D } \\
\text { - Others (vitamins K, group B, Mg, K } \\
\text {...) }\end{array}$ \\
\hline & Lifestyle & $\begin{array}{l}\text { - Solar exposure } \\
\text { - Physical exercise } \\
\text { - Tobacco } \\
\text { - Alcohol }\end{array}$ \\
\hline \multirow[t]{2}{*}{$\begin{array}{l}\text { Partly } \\
\text { modifiable }\end{array}$} & $\begin{array}{l}\text { High risk } \\
\text { diseases }\end{array}$ & $\begin{array}{l}\text { - Prematurity } \\
\text { - Pregnancy and nursing in } \\
\text { adolescents } \\
\text { - Intestinal malabsorption } \\
\text { - Cystic fibrosis } \\
\text { - Celiac disease } \\
\text { - Inflammatory bowel disease } \\
\text { - Food allergies } \\
\text { - Chronic lactose intolerance } \\
\text { - Chronic liver disease } \\
\text { - Chronic kidney disease } \\
\text { - Cerebral palsy } \\
\text { - Chronic rheumatic diseases ... }\end{array}$ \\
\hline & Hormonal & $\begin{array}{l}\text { - Treatment with glucocorticoids } \\
\text { - Hyperparathyroidism } \\
\text { - Hypogonadism }\end{array}$ \\
\hline \multirow{3}{*}{$\begin{array}{l}\text { Non- } \\
\text { modifiable }\end{array}$} & Genetics & \\
\hline & Sex & \\
\hline & Ethnicity & \\
\hline
\end{tabular}

advisable in children and adolescents with low BMD or osteoporosis, especially those patients with a low dietary intake.

Likewise, ensuring proper vitamin $\mathrm{D}_{3}$ intake is recommended in order to maintain plasmatic levels of 25hydroxyvitamin $\mathrm{D}_{3}$ higher than $50 \mathrm{nmol} / \mathrm{l}(20 \mathrm{ng} / \mathrm{dL})$.

Table 6 shows the recommended daily intake of calcium and vitamin D for healthy children [103]. The optimal intake for children with disorders that may interfere with intestinal absorption or modify calcium metabolism remains unknown [41]. Thus, initially, supplementation should be prescribed with respect to these recommendations and subsequently be modified according to plasmatic 25hydroxyvitamin $\mathrm{D}_{3}$, intact paratohormone (iPTH) and calciuria, which must be monitored every 6-12 months.

Table 5 Daily calcium and vitamin D requirements according to age

\begin{tabular}{lll}
\hline Age & Calcium $(\mathrm{mg})$ & Vitamin D (IU) \\
\hline $0-6$ months & 200 & 400 \\
6-12 months & 260 & 400 \\
1-3 years & 700 & 600 \\
4-8 years & 1000 & 600 \\
9-18 years & 1300 & 600 \\
\hline
\end{tabular}

\section{Bisphosphonates}

BPs are synthetic analogs of pyrophosphate that inhibit bone resorption. They selectively concentrate and increase $\mathrm{BMD}$ in high remodeling rates skeleton areas [115]. They are hydrophilic drugs with low intestinal absorption $(<1 \%)$ and high distribution volumes that are excreted in urine. Thus, dosages must be adjusted according to glomerular filtrate. Moreover, they are characterized by a very slow elimination from bone tissue, and remain in the body for years after treatment [115].

Knowledge on the mid- and long-term safety of these drugs is constantly increasing [100]. Thus, some authors recommend their use as long as osteoporotic criteria are met, particularly in those patients with long bones and VF and who exhibit poor potential for spontaneous recovery (age at puberty, risk factor persistence, etc.) [116].

To date, BPs have only been prescribed as a secondary prevention measure. In other words, once the first fracture occurs. Their use is intended to prevent the appearance of new fragility fractures. It is currently known that they confer a positive effect on BMD [9, 84-87], and there is increasing knowledge regarding their long-term safety [100]. On the other hand, if the peak bone mass reached at the end of the growth stage is not optimal, osteoporosis is more likely to develop during the later stages of life [3]. On the basis of the above data, our working group recommends that clinicians consider treatment with BPs for those patients without osteoporosis, but low BMD in early puberty, with low Z-scores and decreasing trajectories.

In any case, BPs are used off label in childhood osteoporosis, so informed consent must be obtained when they are prescribed.

Second and third generation BPs are the most commonly used BPs in children. Some of them are intravenously administered and others orally [100]. Oral BPs are widely used in adulthood osteoporosis, and some studies have demonstrated that they increase BMD and decrease fracture risk in patients with Osteogenesis Imperfecta. Nevertheless, in contrast to intravenous BPs, they lack sufficient potency to induce remodeling after VF [117] and are contraindicated in patients with esophagitis risk factor; e.g., gastroesophageal reflux or hiatal hernia. Intravenous BPs are preferred for pediatric osteoporosis, and oral BPs are only used for patients with mild forms of osteoporosis, without VF, when intravenous administration is contraindicated for any reason, or during the treatment maintenance phase [100].

Table 8 shows doses and dosing intervals for the most commonly used BPs in pediatrics [100].

The optimal treatment duration is not clearly defined and is currently based on expert recommendations [116]. We propose discontinuing or progressively 
Table 6 Basic Diagnostic Studies

\begin{tabular}{ll}
\hline $\begin{array}{l}\text { Laboratory test } \\
\text { Blood count }\end{array}$ & Variables to analyze \\
Blood chemistry & $\begin{array}{l}\text { Calcium, ionized calcium, phosphorus, } \\
\text { magnesium, total proteins, creatinine, urea, } \\
\text { glucose, 25-hydroxyvitamin } \text { D }_{3} \text { PTH, TSH, free T4 }\end{array}$ \\
$\begin{array}{l}\text { 24-hour urine } \\
\text { chemistry }\end{array}$ & $\begin{array}{l}\text { Calcium, phosphorus, creatinine, tubular } \\
\text { phosphorus reabsorption, sodium }\end{array}$ \\
$\begin{array}{l}\text { Urine screening } \\
\text { Bone turnover } \\
\text { makers }\end{array}$ & $\begin{array}{l}\text { Ca/Creatinine }{ }^{a} \\
\text { Total alkaline phosphatase }\end{array}$ \\
\hline
\end{tabular}

${ }^{a}$ Sample from a single urination, preferably first one in the morning

decreasing BPs dosing for those patients who have not presented fractures during the preceding year and who have attained a Z-score higher than -2 .

\section{Follow-up}

The aim of follow-up in patients with osteoporosis risk factors is to identify those candidates who need to start or maintain specific treatments. For such patients and those with an established osteoporosis diagnosis, follow-up should be continued as long as risk factors persist or while treatment is maintained with calcium and/or vitamin $\mathrm{D}_{3}$, BPs or other medications for osteoporosis [49, 51, 74].

Clinical, radiological and analytical parameters should be monitored. Assessing the number of fragility fractures and pain episodes is important. In terms of densitometry, variations in Z-scores are relevant. The optimal frequency for DXA performance is insufficiently defined [74]. Our recommendation is to repeat DXA after one year, and then every 1-2 year thereafter according to the patient's trajectory, with a minimum interval between checks of 6-12 months.

It is also crucial to perform a radiological assessment of VF, since they are frequently asymptomatic and can appear even in patients with Z-scores higher than -2 [23]. Moreover, their evolution can lead to changes in treatment [116]. There are no studies that have definitively determined how often VF should be monitored, although some authors propose lateral spine $\mathrm{x}$-rays on an annual or biannual basis [23]. We propose their

Table 7 Analytical determinations to make based on suspicion

\begin{tabular}{ll}
\hline & Studies \\
\hline 2 & Immunoglobulins \\
3 & Anti-transglutaminase IgA antibodies \\
4 & Cortisol \\
5 & Prolactin \\
6 & FSH, LH, testosterone \\
7 & Homocysteine \\
& Genetic studies (genes related to osteogenesis imperfecta \\
\hline
\end{tabular}

frequency be individualized according to the patient's risk factors, with a minimum period of 6 months and a maximum period of 2 years.

In addition, no studies or guidelines have established the optimal periodicity for assessing phosphocalcic metabolism. Our recommendation is to make an analytical determination on an annual basis.

In regard to patients receiving calcium and vitamin $\mathrm{D}$ supplementation, since the optimal intake for children and adolescents suffering from chronic diseases is unknown [41], doses should be modified according to calciuria and plasmatic levels of 25-hydroxyvitamin $\mathrm{D}_{3}$ and iPTH. The optimal frequency for monitoring these parameters is unknown [49], although some authors advocate that determinations should be made every $3-12$ months $[49,51]$. Our working group recommends that levels of 25-hydroxyvitamin $\mathrm{D}_{3}$ should be determined every 6-12 months, or after 3-6 months after a dose change. Furthermore, an annual determination of calciuria is recommended. A renal ultrasound should be conducted to rule out nephrocalcinosis in the event of calciuria increase, or when urine collection is not possible.

Regarding children being treated with BPs, there are no studies that have determined an optimal frequency for analytical checks. Our group recommends monitorization prior to each infusion for patients receiving intravenous BPs, and every 6 months for patients taking BPs orally.

\section{Corticosteroid-induced osteoporosis}

GCs are widely used with a proven effectiveness in numerous pediatric diseases. However, they carry multiple side effects, and are associated with decreased BMD and bone fragility fractures [118].

Patients treated with systemic GCs lose bone mass more markedly during the first 3-6 months of treatment, mainly trabecular bone [118]. This loss depends on the dose and treatment duration $[119,120]$. Although lower doses are less harmful than higher doses, there appears to be no unequivocally safe dose since fracture risk have been reported to persist with prednisone (or equivalent) doses of 2.5 a $7.5 \mathrm{mg} /$ day [118].

Thus, as in other patients with osteoporosis risk factors, monitoring BMD and VF occurrence is advisable. In the absence of clear data on the optimal time for a DXA in this group, we recommend performing a DXA during the first 6 months of treatment, and repeating it every 9-12 months if treatment continues.

Regarding VF screening, some studies reported an incidence rate of around 10\% during the first year, with nearly $50 \%$ of such cases being asymptomatic [70, 71]. For this reason, it is advisable to assess these patients using imaging technique at the beginning of treatment, and thereafter annually while GCs are maintained. 
Table 8 Doses and dosing intervals for the most commonly used BPs in pediatrics

\begin{tabular}{|c|c|c|}
\hline Drug & Administration & Dose \\
\hline $\begin{array}{l}\text { Pamidronate } \\
\text { (2nd generation) }\end{array}$ & $\begin{array}{l}\text { Intravenous (dilute in } 100-250 \mathrm{ml} \text { physiological saline solution, } \\
\text { in 3-4 hours) }\end{array}$ & $\begin{array}{l}<1 \text { year: } 0.5 \mathrm{mg} / \mathrm{kg} \text { every } 2 \text { months } \\
1-2 \text { years: } 0.25-0.5 \mathrm{mg} / \mathrm{kg} / \text { day } 3 \text { days every } 3 \text { months } \\
2-3 \text { years: } 0.375-0.75 \mathrm{mg} / \mathrm{kg} / \text { day } 3 \text { days every } 3 \text { months } \\
>3 \text { years: } 0.5-1 \mathrm{mg} / \mathrm{kg} / \text { day } 3 \text { days every } 4 \text { months } \\
\text { Maximum dose: } 60 \mathrm{mg} / \text { dose and } 11.5 \mathrm{mg} / \mathrm{kg} / \text { year }\end{array}$ \\
\hline $\begin{array}{l}\text { Neridronate } \\
\text { (3rd generation) }\end{array}$ & $\begin{array}{l}\text { Intravenous (dilute in } 200-250 \mathrm{ml} \text { physiological saline solution, } \\
\text { in } 3 \text { hours) }\end{array}$ & $1-2 \mathrm{mg} / \mathrm{kg} /$ day every $3-4$ months \\
\hline $\begin{array}{l}\text { Zolendronate } \\
\text { (3rd generation) }\end{array}$ & $\begin{array}{l}\text { Intravenous (dilute in } 50 \mathrm{ml} \text { physiological saline solution, } \\
\text { in 30-45 min) }\end{array}$ & $0.0125-0.05 \mathrm{mg} / \mathrm{kg}$ every $6-12$ months (maximum dose $4 \mathrm{mg}$ ) \\
\hline $\begin{array}{l}\text { Alendronate } \\
\text { (2nd generation) }\end{array}$ & Oral & $\begin{array}{l}1-2 \mathrm{mg} / \mathrm{kg} / \text { week } \\
\text { < } 40 \mathrm{~kg}: 5 \mathrm{mg} / \text { day or } 35 \mathrm{mg} / \text { week } \\
\text { > } 40 \mathrm{~kg}: 10 \mathrm{mg} / \text { day or } 70 \mathrm{mg} / \text { week } \\
\text { Maximum dose: } 70 \mathrm{mg} / \text { week }\end{array}$ \\
\hline $\begin{array}{l}\text { Risendronate } \\
\text { (3rd generation) }\end{array}$ & Oral & $\begin{array}{l}15 \mathrm{mg} / \text { week }(<40 \mathrm{~kg}) ; 30 \mathrm{mg} / \text { week (> } 40 \mathrm{~kg}) \\
\text { Maximum dose: } 30 \mathrm{mg} / \text { week }\end{array}$ \\
\hline
\end{tabular}

The Spanish Rheumatology Society Consensus [121] holds that the prevention of GIOP must begin as early as possible for all patients receiving doses higher than 5 $\mathrm{mg} /$ day of prednisone (or equivalent) for more than three months. Preventive actions include prescribing the lowest possible dose of GCs to control the underlying disease, as well as encouraging physical exercise, avoiding toxic products, such as tobacco and alcohol, and ensuring a balanced diet with the required intake of calcium and vitamin D [121]. In fact, a recent systemic review concluded that calcium and vitamin D supplementation should be started with the same dose recommended for healthy children in all children on GCs, particularly when treatment is expected to last more than 3 months, as a preventive action against GIOP development [95]. In addition, our group recommends maintaining this supplementation for three months after discontinuation of GCs treatment since its effect on bone continues even after treatment has been halted. Nevertheless, no studies have determined an optimal period of supplementation. This same review recommends the use of BPs for preventive purposes [95], despite the lack of any comprehensive data. Our own working group does not consider its systematic use in the absence of fragility fractures. Nevertheless, its effectiveness is proven when GIOP has been established; i.e., when pathological fractures are clearly evident $[87,95,96]$.

Most studies suggest that an inhaled GCs dose lower than the equivalent of $800 \mathrm{mcg} /$ day of budesonide has only a minimum effect on fracture risk, while higher doses are associated with an accelerated decrease in BMD and a higher risk of fractures. In these patients, although non-pharmacological preventive actions are justified [97, 98, 122], it is not advisable to routinely carry out such procedures as lateral spine $\mathrm{x}$-rays or DXAs, unless these patients have other risk factors [97-99].
Furthermore, the role of calcium and vitamin D supplementation in patients prescribed inhaled GCs has not yet been established, although some groups recommend supplementation for higher risk populations [93].

\section{Conclusion}

In summary, we present herein guidelines for the prevention, diagnosis and treatment of secondary childhood osteoporosis based on the available evidence and expert clinical experience. We believe it can serve as a useful tool that will contribute to the standardization of clinical practice for this pathology. Prophylactic measures, early diagnosis and a proper therapeutic approach are essential to improving bone health, not only in children and adolescents, but also in the adults they will become in the future.

\section{Abbreviations}

BMC: Body mass content; BMD: Body mass density; BPs: Bisphosphonates; CEBM: Centre for Evidence-based Medicine; CTx: Carboxy-terminal telopeptides; DXA: Dual-energy x-ray absorptiometry; GCs: Glucocorticoids; GIOP: Glucocorticoid-induced osteoporosis; iPTH: Intact paratohormone; P1NP: Amino-terminal propeptides from type 1 procollagen; SERPE: Pediatric Rheumathology Spanish Society; UVB: Ultraviolet B; VF: Vertebral fractures

\section{Acknowledgements}

We thank the Spanish Pediatric Rheumatology Society, Laboratorios Rubió and Alexion Pharma for granting.

We thank Dra. Estíbaliz Loza, InMusc Medical Director for her assistance in conducting the literature review, in determining the recommendations level of evidence and in setting up the Delphi survey.

Thanks also to the Spanish Rheumatology Society for the original manuscript translation.

\section{Authors' contributions}

RGZ coordinated the project, conducted a literature review about calcium and vitamin D supplementation in secondary osteoporosis in children, provided recommendations based on evidence, was a major contributor in writing the manuscript, read and approved the final manuscript. RBT conducted a literature review about bisphosphonates in secondary osteoporosis in children, provided recommendations based on evidence, was a major contributor in writing the manuscript, read and approved the final manuscript. BML conducted a literature review about imaging tests used in secondary osteoporosis screening in children, provided 
recommendations based on evidence, read and approved the final manuscript. CMP conducted a literature review about when secondary osteoporosis in children should be suspected, provided recommendations based on evidence, read and approved the final manuscript. NPF conducted a literature review about when secondary osteoporosis in children should be suspected, provided recommendations based on evidence, read and approved the final manuscript. BSP conducted a literature review about glucorticoids-induced osteoporosis in children, provided recommendations based on evidence, read and approved the final manuscript. MMSI conducted a literature review about imaging tests used in secondary osteoporosis screening in children, provided recommendations based on evidence, read and approved the final manuscript. MIGF conducted a literature review about follow-up in secondary osteoporosis in children, provided recommendations based on evidence, read and approved the final manuscript. ARP conducted a literature review about laboratory tests used in secondary osteoporosis screening in children, provided recommendations based on evidence, read and approved the final manuscript. PAR conducted a literature review about secondary osteoporosis prevention in children, provided recommendations based on evidence, read and approved the final manuscript. JCNG conducted a literature review about calcium and vitamin D supplementation in secondary osteoporosis in children, provided recommendations based on evidence, read and approved the final manuscript. MLC conducted a literature review about secondary osteoporosis prevention in children, provided recommendations based on evidence, read and approved the final manuscript. JGG conducted a literature review about laboratory tests used in secondary osteoporosis screening in children, provided recommendations based on evidence, read and approved the final manuscript.

\section{Funding}

This workshop was organized by the Osteogenesis Imperfecta and secondary osteoporosis working group form SERPE. Financial support was provided by a Spanish Pediatric Rheumtology Society scholarship for Pediatric Rheumatology research and Laboratorios Rubió and Alexion Pharma grant.

\section{Availability of data and materials}

Not applicable.

\section{Ethics approval and consent to participate}

Not applicable.

\section{Consent for publication}

Not applicable.

\section{Competing interests}

The authors declare that they have no competing interests.

\section{Author details}

${ }^{1}$ UGC Pediatría. Sección Reumatología Pediátrica, Hospital Regional Universitario de Málaga, Málaga, Spain. Unidad de Reumatología Pediátrica, Hospital Sant Joan de Déu, Barcelona, Spain. ${ }^{3}$ Servicio de Reumatología, Hospital de la Santa Creu i Sant Pau, Barcelona, Spain. ${ }^{4}$ Unidad de Pediatría, Sección Reumatología Pediátrica, Hospital Universitari Son Espases, Palma de Mallorca, Spain. ${ }^{5}$ Unidad de Reumatología, Hospital Universitario Marqués de Valdecilla, Santander, Spain. ${ }^{6}$ UGC Pediatría, Sección Reumatología Pediátrica, Hospital Campus de la Salud, Granada, Spain. ${ }^{7}$ Unidad de Reumatología, Hospital Miguel Servet, Zaragoza, Spain. ${ }^{8}$ Unidad de Pediatría, Sección de Reumatología Pediátrica, Hospital La Fe, Valencia, Spain. ' Unidad de Reumatología, Hospital General de Villalba, Madrid, Spain. ${ }^{10}$ Unidad de Pediatría, Sección de Reumatología Pediátrica, Hospital Virgen de la Arriaxaca, Murcia, Spain. ${ }^{11}$ Servicio de Reumatología, Hospital General Universitario Gregorio Marañón, Madrid, Spain. ${ }^{12}$ Servicio de Reumatología Hospital Vall d'Hebron, Barcelona, Spain. ${ }^{13}$ Servicio de Reumatología, Complejo Hospitalario Universitario A Coruña, A Coruña, Spain.

${ }^{14}$ Osteogenesis Imperfecta and Secondary Osteoporosis Working Group from the Spanish Pediatric Rheumatology Society, Madrid, Spain.
Received: 2 October 2019 Accepted: 3 February 2020

Published online: 24 February 2020

\section{References}

1. Peck WA et al.Consensus development conference: diagnosis, prophylaxis, and treatment of osteoporosis. Am J Med. 1993;94(6):646-50.

2. Wade SW, Strader C, Fitzpatrick LA, Anthony MS, O'Malley CD. Estimating prevalence of osteoporosis: examples from industrialized countries. Arch Osteoporos. 2014;9:182.

3. Yeste D, Carrascosa A. Valoración e interpretación de la masa ósea en la infancia y la adolescencia. Pediatr Integr. 2015;XIX(6):436.e1-9.

4. Galindo Zavala R, Núñez Cuadros E, Díaz Cordovés-Rego G, Urda Cardona AL. Advances in the treatment of secondary osteoporosis. An Pediatr. 2014; 81(6):399.e1-7.

5. Gordon CM, Leonard MB, Zemel BS. 2013 pediatric position development conference: executive summary and reflections. J Clin Densitom. 2014;17(2): 219-24.

6. Baim S, Leonard MB, Bianchi ML, Hans DB, Kalkwarf HJ, Langman CB, et al. Official positions of the International Society for Clinical Densitometry and executive summary of the 2007 ISCD pediatric position development conference. J Clin Densitom. 2008;11(1):6-21.

7. Mir-Perelló C, Galindo Zavala R, González Fernández MI, Graña Gil J, Sevilla Pérez B, Magallares López B, et al. Prevention and early diagnosis of childhood osteoporosis: are we doing the right thing? Rev Osteoporos y Metab Miner. 2018;10(1):30-6.

8. Fehlings D, Switzer L, Agarwal P, Wong C, Sochett E, Stevenson R, et al. Informing evidence-based clinical practice guidelines for children with cerebral palsy at risk of osteoporosis: a systematic review. Dev Med Child Neurol. 2012;54(2):106-16.

9. Dwan K, Phillipi CA, Steiner RD, Basel D. Bisphosphonate therapy for osteogenesis imperfecta. Cochrane Database Syst Rev. 2016 Oct 19;10: CD005088.

10. Bhardwaj A, Swe KMM, Sinha NK, Osunkwo I. Treatment for osteoporosis in people with ß-thalassaemia. In: Swe KMM, editor. Cochrane Database Sys Rev. 2016;10(3):CD010429.

11. Birnkrant DJ, Bushby K, Bann CM, Alman BA, Apkon SD, Blackwell A, et al. Diagnosis and management of Duchenne muscular dystrophy, part 2: respiratory, cardiac, bone health, and orthopaedic management. Lancet Neurol. 2018;17(4):347-61.

12. Cervera A, Cela E, González A, Berrueco R, Argiles B, Badell I, et al. Guía de práctica clínica de la talasemia mayor e intermedia en pediatría.1ST ed. CEGE; 2015.

13. Fong $C Y$, Mallick AA, Burren CP, Patel JS. Evaluation and management of bone health in children with epilepsy on long-term antiepileptic drugs: United Kingdom survey of paediatric neurologists. Eur J Paediatr Neurol. 2011:15(5):417-23.

14. Hall CH, Hewitt G, Stevens SL. Assessment and management of bone health in adolescents with anorexia nervosa part one: assessment of bone health in adolescents. J Pediatr Adolesc Gynecol. 2008;21(3):155-7.

15. Jefferson A, Leonard $H$, Siafarikas A, Woodhead H, Fyfe S, Ward LM, et al. Clinical guidelines for Management of Bone Health in Rett syndrome based on expert consensus and available evidence. PLoS One. 2016;11(2): e0146824.

16. Tangpricha V, Kelly A, Stephenson A, Maguiness K, Enders J, Robinson KA, et al. An update on the screening, diagnosis, management, and treatment of vitamin D deficiency in individuals with cystic fibrosis: evidence-based recommendations from the Cystic Fibrosis Foundation. J Clin Endocrinol Metab. 2012;97(4):1082-93.

17. Wasilewski-Masker K, Kaste SC, Hudson MM, Esiashvili N, Mattano LA Meacham LR. Bone mineral density deficits in survivors of childhood cancer: long-term follow-up guidelines and review of the literature. Pediatrics. 2008. 121(3):e705-13.

18. Zhang $Y$, Milojevic D. Protecting bone health in pediatric rheumatic diseases: pharmacological considerations. Paediatr Drugs. 2017;19(3): 193-211.

19. Shaw NJ. Management of osteoporosis in children. Eur J Endocrinol. 2008; 159(Suppl):S33-9.

20. Cassidy JT, Hillman LS. Abnormalities in skeletal growth in children with juvenile rheumatoid arthritis. Rheum Dis Clin N Am. 1997;23(3):499-522.

21. Ma NS, Gordon CM. Pediatric osteoporosis: where are we now? J Pediatr. 2012;161(6):983-90. 
22. Paganelli M, Albanese C, Borrelli O, Civitelli F, Canitano N, Viola F, et al. Inflammation is the main determinant of low bone mineral density in pediatric inflammatory bowel disease. Inflamm Bowel Dis. 2007;13(4): 416-23.

23. Ward LM, Konji VN, Ma J. The management of osteoporosis in children. Osteoporos Int. 2016;27(7):2147-79.

24. Mandel K, Atkinson S, Barr RD, Pencharz P. Skeletal morbidity in childhood acute lymphoblastic leukemia. J Clin Oncol. 2004;22(7):1215-21.

25. Cromer BA, Bonny AE, Stager M, Lazebnik R, Rome E, Ziegler J, et al. Bone mineral density in adolescent females using injectable or oral contraceptives: a 24-month prospective study. Fertil Steril. 2008;90(6):2060-7.

26. Cibula D, Skrenkova J, Hill M, Stepan JJ. Low-dose estrogen combined oral contraceptives may negatively influence physiological bone mineral density acquisition during adolescence. Eur J Endocrinol. 2012;166(6):1003-11.

27. Lopez LM, Chen M, Mullins S, Curtis KM, Helmerhorst FM. Steroidal contraceptives and bone fractures in women: evidence from observational studies. Cochrane Database Syst Rev. 2012;15(8):CD009849.

28. Souverein PC, Webb DJ, Weil JG, Van Staa TP, Egberts ACG. Use of antiepileptic drugs and risk of fractures: case-control study among patients with epilepsy. Neurology. 2006;66(9):1318-24.

29. Soyka LA, Misra M, Frenchman A, Miller KK, Grinspoon S, Schoenfeld DA, et al. Abnormal bone mineral accrual in adolescent girls with anorexia nervosa. J Clin Endocrinol Metab. 2002;87(9):4177-85.

30. Turner JM, Bulsara MK, McDermott BM, Byrne GC, Prince RL, Forbes DA. Predictors of low bone density in young adolescent females with anorexia nervosa and other dieting disorders. Int J Eat Disord. 2001;30(3):245-51.

31. Behringer M, Gruetzner S, McCourt M, Mester J. Effects of weight-bearing activities on bone mineral content and density in children and adolescents: a meta-analysis. J Bone Miner Res. 2014;29(2):467-78.

32. Dong Y, Pollock N, Stallmann-Jorgensen IS, Gutin B, Lan L, Chen TC, et al. Low 25-hydroxyvitamin D levels in adolescents: race, season, adiposity, physical activity, and fitness. Pediatrics. 2010;125(6):1104-11.

33. Moro M, van der Meulen MC, Kiratli BJ, Marcus R, Bachrach LK, Carter DR. Body mass is the primary determinant of midfemoral bone acquisition during adolescent growth. Bone. 1996;19(5):519-26.

34. Goulding A, Grant AM, Williams SM. Bone and body composition of children and adolescents with repeated forearm fractures. J Bone Miner Res. 2005:20(12):2090-6.

35. Golden NH, Abrams SA. Optimizing bone health in children and adolescents. Pediatrics. 2014;134(4):e1229-43.

36. Kalkwarf HJ, Khoury JC, Lanphear BP. Milk intake during childhood and adolescence, adult bone density, and osteoporotic fractures in US women. Am J Clin Nutr. 2003;77(1):257-65.

37. Watanabe R, Inoue D. Smoking and bone. Clin Calcium. 2016;26(10):1445-50.

38. Maurel DB, Boisseau N, Benhamou CL, Jaffre C. Alcohol and bone: review of dose effects and mechanisms. Osteoporos Int. 2012;23(1):1-16.

39. Alqahtani FF, Offiah AC. Diagnosis of osteoporotic vertebral fractures in children. Pediatr Radiol. 2019;49(3):283-96

40. Huncharek M, Muscat J, Kupelnick B. Impact of dairy products and dietary calcium on bone-mineral content in children: results of a meta-analysis. Bone. 2008:43(2):312-21.

41. Uziel Y, Zifman E, Hashkes PJ. Osteoporosis in children: pediatric and pediatric rheumatology perspective: a review. Pediatr Rheumatol Online J. 2009;7:16

42. Tan VPS, Macdonald HM, Kim S, Nettlefold L, Gabel L, Ashe MC, et al. Influence of physical activity on bone strength in children and adolescents: a systematic review and narrative synthesis. J Bone Miner Res. 2014;29(10): 2161-81.

43. Hind K, Burrows M. Weight-bearing exercise and bone mineral accrual in children and adolescents: a review of controlled trials. Bone. 2007;40(1):14-27.

44. Field AE, Gordon CM, Pierce LM, Ramappa A, Kocher MS. Prospective study of physical activity and risk of developing a stress fracture among preadolescent and adolescent girls. Arch Pediatr Adolesc Med. 2011; 165(8):723-8.

45. Tenforde AS, Fredericson M. Influence of sports participation on bone health in the young athlete: a review of the literature. PM R. 2011;3(9):861-7.

46. Specker B, Thiex NW, Sudhagoni RG. Does exercise influence pediatric bone? A systematic review. Clin Orthop Relat Res. 2015;473(11):3658-72.

47. Dubnov-Raz G, Azar M, Reuveny R, Katz U, Weintraub M, Constantini NW. Changes in fitness are associated with changes in body composition and bone health in children after cancer. Acta Paediatr. 2015;104(10):1055-61.
48. Hough JP, Boyd RN, Keating JL. Systematic review of interventions for low bone mineral density in children with cerebral palsy. Pediatrics. 2010;125(3):e670-8.

49. Munns CF, Shaw N, Kiely M, Specker BL, Thacher TD, Ozono K, et al. Global consensus recommendations on prevention and Management of Nutritional Rickets. Horm Res Paediatr. 2016;85(2):83-106.

50. Holmlund-Suila E, Koskivirta P, Metso T, Andersson S, Makitie O, Viljakainen HT. Vitamin D deficiency in children with a chronic illness-seasonal and agerelated variations in serum 25 -hydroxy vitamin D concentrations. PLoS One. 2013;8(4):e60856.

51. Misra M, Pacaud D, Petryk A, Collett-Solberg P, Kappy M. Drug, et al. vitamin $D$ deficiency in children and its management: review of current knowledge and recommendations. Pediatrics. 2008;122(2):398-417.

52. Saraff $V$, Högler W. Endocrinology and adolescence: osteoporosis in children: diagnosis and management. Eur J Endocrinol. 2015;173(6):R185-97.

53. Rauchenzauner M, Schmid A, Heinz-Erian P, Kapelari K, Falkensammer G, Griesmacher A, et al. Sex- and age-specific reference curves for serum markers of bone turnover in healthy children from 2 months to 18 years. J Clin Endocrinol Metab. 2007;92(2):443-9.

54. Szulc P, Seeman E, Delmas PD. Biochemical measurements of bone turnover in children and adolescents. Osteoporos Int. 2000;11(4):281-94.

55. Yang $L$, Grey $\mathrm{V}$. Pediatric reference intervals for bone markers. Clin Biochem. 2006;39(6):561-8.

56. Eapen E, Grey V, Don-Wauchope A, Atkinson SA. Bone health in childhood: usefulness of biochemical biomarkers. EJIFCC. 2008;19(2):123-36.

57. Jurimae J. Interpretation and application of bone turnover markers in children and adolescents. Curr Opin Pediatr. 2010;22(4):494-500.

58. Michalus I, Chlebna-Sokol D, Rusinska A, Jakubowska-Pietkiewicz E, Kulinska-Szukalska K. Evaluation of bone mineral density and bone metabolism in children with multiple bone fractures. Ortop Traumatol Rehabil. 2008;10(6):602-12.

59. Warden SJ, Hill KM, Ferira AJ, Laing EM, Martin BR, Hausman DB, et al. Racial differences in cortical bone and their relationship to biochemical variables in black and white children in the early stages of puberty. Osteoporos Int. 2013;24(6):1869-79.

60. Manjon Llorente G, Fernandez-Espuelas C, Gonzalez Lopez JM, Ruiz-Echarri MP, Baldellou VA. Normal values of bone turnover markers in childhood. An Pediatr (Barc). 2004;60(4):330-6

61. Fischer D-C, Mischek A, Wolf S, Rahn A, Salweski B, Kundt G, et al. Paediatric reference values for the C-terminal fragment of fibroblast-growth factor-23, sclerostin, bone-specific alkaline phosphatase and isoform $5 \mathrm{~b}$ of tartrateresistant acid phosphatase. Ann Clin Biochem. 2012;49:546-53.

62. Crabtree NJ, Hogler W, Cooper MS, Shaw NJ. Diagnostic evaluation of bone densitometric size adjustment techniques in children with and without low trauma fractures. Osteoporos Int. 2013;24(7):2015-24.

63. Clark EM, Ness AR, Bishop NJ, Tobias JH. Association between bone mass and fractures in children: a prospective cohort study. J Bone Miner Res. 2006;21(9):1489-95

64. Schousboe JT, Shepherd JA, Bilezikian JP, Baim S. Executive summary of the 2013 International Society for Clinical Densitometry Position Development Conference on bone densitometry. J Clin Densitom. 2013;16(4):455-66.

65. Adiotomre E, Summers L, Allison A, Walters SJ, Digby M, Broadley P, et al. Diagnostic accuracy of DXA compared to conventional spine radiographs for the detection of vertebral fractures in children. Eur Radiol. 2017;27(5):2188-99.

66. Binkovitz LA, Henwood MJ. Pediatric DXA: technique and interpretation. Pediatr Radiol. 2007:37(1):21-31.

67. Leonard MB, Feldman HI, Zemel BS, Berlin JA, Barden EM, Stallings VA Evaluation of low density spine software for the assessment of bone mineral density in children. J Bone Miner Res. 1998;13(11):1687-90.

68. Zemel BS, Kalkwarf HJ, Gilsanz V, Lappe JM, Oberfield S, Shepherd JA, et al. Revised reference curves for bone mineral content and areal bone minera density according to age and sex for black and non-black children: results of the bone mineral density in childhood study. J Clin Endocrinol Metab. 2011;96(10):3160-9.

69. Zemel BS, Leonard MB, Kelly A, Lappe JM, Gilsanz V, Oberfield S, et al. Height adjustment in assessing dual energy $x$-ray absorptiometry measurements of bone mass and density in children. J Clin Endocrinol Metab. 2010;95(3):1265-73

70. LeBlanc CMA, Ma J, Taljaard M, Roth J, Scuccimarri R, Miettunen P, et al. Incident vertebral fractures and risk factors in the first three years following glucocorticoid initiation among pediatric patients with rheumatic disorders. J Bone Miner Res. 2015;30(9):1667-75. 
71. Phan V, Blydt-Hansen T, Feber J, Alos N, Arora S, Atkinson S, et al. Skeletal findings in the first 12 months following initiation of glucocorticoid therapy for pediatric nephrotic syndrome. Osteoporos Int. 2014;25(2):627-37.

72. Makitie O, Doria AS, Henriques F, Cole WG, Compeyrot S, Silverman E, et al. Radiographic vertebral morphology: a diagnostic tool in pediatric osteoporosis. J Pediatr. 2005;146(3):395-401.

73. Mäyränpää MK, Helenius I, Valta H, Mäyränpää MI, Toiviainen-Salo S, Mäkitie O. Bone densitometry in the diagnosis of vertebral fractures in children: accuracy of vertebral fracture assessment. Bone. 2007;41(3):353-9.

74. Bianchi ML, Leonard MB, Bechtold S, Hogler W, Mughal MZ, Schonau E, et al. Bone health in children and adolescents with chronic diseases that may affect the skeleton: the 2013 ISCD pediatric official positions. J Clin Densitom. 2014;17(2):281-94.

75. Shepherd JA, Wang L, Fan B, Gilsanz V, Kalkwarf HJ, Lappe J, et al. Optimal monitoring time interval between DXA measures in children. J Bone Miner Res. 2011;26(11):2745-52.

76. Abrams SA. Building bones in babies: can and should we exceed the human milk-fed infant's rate of bone calcium accretion? Nutr Rev. 2006; 64(11):487-94

77. Oen K, Malleson PN, Cabral DA, Rosenberg AM, Petty RE, Cheang M. Disease course and outcome of juvenile rheumatoid arthritis in a multicenter cohort. J Rheumatol. 2002;29(9):1989-99.

78. Lien G, Flato B, Haugen M, Vinje O, Sorskaar D, Dale K, et al. Frequency of osteopenia in adolescents with early-onset juvenile idiopathic arthritis: a long-term outcome study of one hundred five patients. Arthritis Rheum. 2003;48(8):2214-23.

79. Huber AM, Gaboury I, Cabral DA, Lang B, Ni A, Stephure D, et al. Prevalent vertebral fractures among children initiating glucocorticoid therapy for the treatment of rheumatic disorders. Arthritis Care Res (Hoboken). 2010;62(4): $516-26$.

80. Winzenberg TM, Powell S, Shaw KA, Jones G. Vitamin D supplementation for improving bone mineral density in children. Cochrane Database Syst Rev. 2010;10:CD006944.

81. Winzenberg T, Powell S, Shaw KA, Jones G. Effects of vitamin D supplementation on bone density in healthy children: systematic review and meta-analysis. BMJ. 2011;342:c7254.

82. Lovell DJ, Glass D, Ranz J, Kramer S, Huang B, Sierra Rl, et al. A randomized controlled trial of calcium supplementation to increase bone mineral density in children with juvenile rheumatoid arthritis. Arthritis Rheum. 2006; 54(7):2235-42.

83. Jekovec-Vrhovsek M, Kocijancic A, Prezelj J. Effect of vitamin D and calcium on bone mineral density in children with CP and epilepsy in full-time care. Dev Med Child Neurol. 2000;42(6):403-5.

84. Kim MJ, Kim S-N, Lee I-S, Chung S, Lee J, Yang Y, et al. Effects of bisphosphonates to treat osteoporosis in children with cerebral palsy: a meta-analysis. J Pediatr Endocrinol Metab. 2015;28(11-12):1343-50.

85. Ozel S, Switzer L, Macintosh A, Fehlings D. Informing evidence-based clinical practice guidelines for children with cerebral palsy at risk of osteoporosis: an update. Dev Med Child Neurol. 2016;58(9):918-23.

86. Bryan ML, Worthington MA, Parsons K. Treatment of osteoporosis/ osteopenia in pediatric leukemia and lymphoma. Ann Pharmacother. 2009; 43(4):714-20.

87. Ward L, Tricco AC, Phuong P, Cranney A, Barrowman N, Gaboury I, et al. Bisphosphonate therapy for children and adolescents with secondary osteoporosis. Cochrane Database Syst Rev. 2007:4:CD005324.

88. Thornton J, Ashcroft DM, Mughal MZ, Elliott RA, O'Neill TW, Symmons D. Systematic review of effectiveness of bisphosphonates in treatment of low bone mineral density and fragility fractures in juvenile idiopathic arthritis. Arch Dis Child. 2006;91(9):753-61.

89. Ooi HL, Briody J, Biggin A, Cowell CT, Munns CF. Intravenous zoledronic acid given every 6 months in childhood osteoporosis. Horm Res Paediatr. 2013;80(3):179-84

90. Simm PJ, Johannesen J, Briody J, McQuade M, Hsu B, Bridge C, et al Zoledronic acid improves bone mineral density, reduces bone turnover and improves skeletal architecture over 2 years of treatment in children with secondary osteoporosis. Bone. 2011:49(5):939-43.

91. Thornton J, Ashcroft D, O'Neill T, Elliott R, Adams J, Roberts C, et al. A systematic review of the effectiveness of strategies for reducing fracture risk in children with juvenile idiopathic arthritis with additional data on longterm risk of fracture and cost of disease management. Health Technol Assess. 2008;12(3):iii - ix, xi - xiv, 1-208.
92. Bishop N, Braillon P, Burnham J, Cimaz R, Davies J, Fewtrell M, et al. Dualenergy $\mathrm{X}$-ray aborptiometry assessment in children and adolescents with diseases that may affect the skeleton: the 2007 ISCD pediatric official positions. J Clin Densitom. 2008;11(1):29-42.

93. Hansen KE, Kleker B, Safdar N, Bartels CM. A systematic review and metaanalysis of glucocorticoid-induced osteoporosis in children. Semin Arthritis Rheum. 2014;44(1):47-54.

94. Bachrach LK, Gordon CM. Bone densitometry in children and adolescents. Pediatrics. 2016;138(4):e20162398.

95. Jayasena A, Atapattu N, Lekamwasam S. Treatment of glucocorticoidinduced low bone mineral density in children: a systematic review. Int J Rheum Dis. 2015;18(3):287-93.

96. Bell JM, Shields MD, Watters J, Hamilton A, Beringer T, Elliott M, et al. Interventions to prevent and treat corticosteroid-induced osteoporosis and prevent osteoporotic fractures in Duchenne muscular dystrophy. Cochrane Database Syst Rev. 2017;1:CD010899.

97. Gregson RK, Rao R, Murrills AJ, Taylor PA, Warner JO. Effect of inhaled corticosteroids on bone mineral density in childhood asthma: comparison of fluticasone propionate with beclomethasone dipropionate. Osteoporos Int. 1998;8(5):418-22.

98. Altintas DU, Karakoc GB, Can S, Yilmaz M, Kendirli SG. The effects of long term use of inhaled corticosteroids on linear growth, adrenal function and bone mineral density in children. Allergol Immunopathol (Madr). 2005;33(4):204-9.

99. Buckley L, Guyatt G, Fink HA, Cannon M, Grossman J, Hansen KE, et al. 2017 American College of Rheumatology Guideline for the prevention and treatment of glucocorticoid-induced osteoporosis. Arthritis Rheumatol (Hoboken, NJ). 2017;69(8):1521-37.

100. Marrani E, Giani T, Simonini G, Cimaz R. Pediatric osteoporosis: diagnosis and treatment considerations. Drugs. 2017;77(6):679-95.

101. Sermet-Gaudelus I, Bianchi ML, Garabedian M, Aris RM, Morton A, Hardin DS, et al. European cystic fibrosis bone mineralisation guidelines. J Cyst Fibros. 2011;10(Suppl 2):S16-23.

102. Hollander MC, Sage JM, Greenler AJ, Pendl J, Avcin T, Espada G, et al. International consensus for provisions of quality-driven care in childhoodonset systemic lupus erythematosus. Arthritis Care Res (Hoboken). 2013; 65(9):1416-23.

103. Martinez Suarez V, Moreno Villares JM, Dalmau Serra J. Comité de Nutrición de la Sociedad Española de Pediatría. Recommended intake of calcium and vitamin D: positioning of the Nutrition Committee of the AEP. An Pediatr (Barc). 2012;77(1):57.e1-8.

104. Ebeling PR, Daly RM, Kerr DA, Kimlin MG. Building healthy bones throughout life: an evidence-informed strategy to prevent osteoporosis in Australia. Med J Aust. 2013;199(S7):S1-S46.

105. Bolland MJ, Avenell A, Baron JA, Grey A, MacLennan GS, Gamble GD, et al. Effect of calcium supplements on risk of myocardial infarction and cardiovascular events: meta-analysis. BMJ. 2010;341:c3691.

106. Winzenberg TM, Shaw K, Fryer J, Jones G. Calcium supplementation for improving bone mineral density in children. Cochrane Database Syst Rev. 2006:2:CD005119

107. Vasikaran S, Eastell R, Bruyere O, Foldes AJ, Garnero P, Griesmacher A, et al. Markers of bone turnover for the prediction of fracture risk and monitoring of osteoporosis treatment: a need for international reference standards. Osteoporos Int. 2011;22(2):391-420.

108. Bauer D, Krege J, Lane N, Leary E, Libanati C, Miller P, et al. National Bone Health Alliance Bone Turnover Marker Project: current practices and the need for US harmonization, standardization, and common reference ranges. Osteoporos Int. 2012;23(10):2425-33.

109. Vasikaran SD, Chubb SA, Schneider HG. Towards optimising the provision of laboratory services for bone turnover markers. Pathology. 2014;46(4):267-73.

110. Mora S, Prinster C, Proverbio MC, Bellini A, de Poli SC, Weber G, et al. Urinary markers of bone turnover in healthy children and adolescents: agerelated changes and effect of puberty. Calcif Tissue Int. 1998;63(5):369-74.

111. Lambert HL, Eastell R, Karnik K, Russell JM, Barker ME. Calcium supplementation and bone mineral accretion in adolescent girls: an 18-mo randomized controlled trial with 2-y follow-up. Am J Clin Nutr. 2008;87(2):455-62.

112. Glendenning P, Chubb SAP, Vasikaran S. Clinical utility of bone turnover markers in the management of common metabolic bone diseases in adults. Clin Chim Acta. 2018:481:161-70.

113. Huang Y, Eapen E, Steele S, Grey V. Establishment of reference intervals for bone markers in children and adolescents. Clin Biochem. 2011; 44(10-11):771-8 
114. Di lorgi N, Maruca K, Patti G, Mora S. Update on bone density measurements and their interpretation in children and adolescents. Best Pract Res Clin Endocrinol Metab. 2018;32(4):477-98.

115. Bachrach LK, Ward LM. Clinical review 1: bisphosphonate use in childhood osteoporosis. J Clin Endocrinol Metab. 2009;94(2):400-9.

116. Simm PJ, Biggin A, Zacharin MR, Rodda CP, Tham E, Siafarikas A, et al. Consensus guidelines on the use of bisphosphonate therapy in children and adolescents. J Paediatr Child Health. 2018;54(3):223-33.

117. Land C, Rauch F, Munns CF, Sahebjam S, Glorieux FH. Vertebral morphometry in children and adolescents with osteogenesis imperfecta: effect of intravenous pamidronate treatment. Bone. 2006;39(4):901-6.

118. Van Staa TP, Leufkens HGM, Cooper C. The epidemiology of corticosteroidinduced osteoporosis: a meta-analysis. Osteoporos Int. 2002;13(10):777-87.

119. Reid IR, Heap SW. Determinants of vertebral mineral density in patients receiving long-term glucocorticoid therapy. Arch Intern Med. 1990;150(12): 2545-8.

120. Canalis E, Mazziotti G, Giustina A, Bilezikian JP. Glucocorticoid-induced osteoporosis: pathophysiology and therapy. Osteoporos Int. 2007;18(10): 1319-28.

121. Perez Edo L, Alonso Ruiz A, Roig Vilaseca D, Garcia Vadillo A, Guañabens Gay N, Peris $P$, et al. 2011 up-date of the consensus statement of the Spanish Society of Rheumatology on osteoporosis. Reumatol Clin. 2011;7(6):357-79.

122. Sharma PK, Malhotra S, Pandhi P, Kumar N. Effect of inhaled steroids on bone mineral density: a meta-analysis. J Clin Pharmacol. 2003;43(2):193-7.

\section{Publisher's Note}

Springer Nature remains neutral with regard to jurisdictional claims in published maps and institutional affiliations.

Ready to submit your research? Choose BMC and benefit from:

- fast, convenient online submission

- thorough peer review by experienced researchers in your field

- rapid publication on acceptance

- support for research data, including large and complex data types

- gold Open Access which fosters wider collaboration and increased citations

- maximum visibility for your research: over $100 \mathrm{M}$ website views per year

At BMC, research is always in progress.

Learn more biomedcentral.com/submissions 